身がその際第四紀学をこなしていれば，立合う必要はな くなるわけである。

考えねばならないもう1つのことは，その層準が国際 的なことばでいえば何に当るかということである．本論 文は主として，この 2 番目の課題に取組えだものとい光 る. 古典的なアルプス水期編年と地中海の海岸段丘とを 真正面からとりあげ，著者自らの踏査もふくめて事細か に紹介解説している労に敬意を表したい.これを読えだ あとで私が感ずることは，「世界の標準層序とは一体何 なのか？」ということである. 一旦確立されたかに見光 ていることでも, 学問の進展とともに，他に席をゆずる ことがあって当然ではないだろうか. たとえば Würm 最盛期ということばを，われわれはしばしば使うが，今 から 2 万年位前のことで, 地球上が寒冷となり，海面が 70〜100m 低下した時期というような意味である．海面 の低下あるいは気候の寒冷化を指標として, 日本とアメ リカとの間で容易に対比することができる．この際アル プスの Würm は, すでに名前として残るだけで, 対比 の仲介役としての直接の必要はなくなっている. それ は, アルプスの Würm と 2 万年前の寒冷期海面低下期 との間の対応が殆んど 100\%確実だから, 安心してその 名を使っているからだといえよう. 同じことは，Riss 水 期，ましてやもっと前の氷期には，当てはまらない. 100\% 確実ではなくなってくるのである.だから，8万 年前の海進だとか，12.5 万年前の海進だとかいらことば が使われだしてきている．これらは国際語としては旨く ないように思える.なぜなら，1つの海進あるいは間水
期を指して，或る人は 12 万年前といったり，或る人は 13 万年前といったりするからである。「下末吉」といら 風に，どこかに模式地を置いて呼称する従来のやりかた がやはりよいだろう。

第四紀学の発展とともに，ぞうやら世界の標準層序地 域はヨーロッパよりも太平洋地域に移した方がよさそう に思えてくる. 特に, 氷河堆積物や氷河地形よりも, 海 岸段丘，それも地殼の隆起しつつある海岸の段丘で，一 層よく編年が可能なことが判ってきた現在，益々そうで ある. 今のところ, 放射性年代測定の進んでいるサンゴ 礁地域が模式地として有利である. そして, 年代測定 · 磁気層序と海面変化乃至気候变化をすべて並行にガッチ リと確立した地域が勝であるもしたと光日本がその国 際標準とならなくても，それに近い仕事をしていれば， 国際標準との対比は易々たることであろう。そうすれ ば，ヨーロッパだろうとアフリカだろうと，新しい期名 で呼ぶようになるから, 考古学者の期待する解答は, お のずから得られることになる.

本論交の著者は，早くから，ここに挙げた第四紀学的 方法を駆使している人であって，その仕事が大成すれば 上のような夢の実現に近いことになるように思えるが， それは私の編見であろうか. 副題の「国際的対比」は, 必ずしもアルプスや地中海の期名を使うこととは限らな い, という点が唯一の批判めいた患見で，その考えも， 実をいえば，前述のように，本論文を読えだ私なりの結 論としてでてきた次第で, 著者の精力的な検討にむしろ 感謝したい.

(東京大学理学部地質学教室)

\title{
論評に対する原著者の回答
}

\section{Author's Reply to the Comments}

\section{1. 市原実氏の批判に答える}

アルプスの水河時代が第四紀地史の中でもつ意義は大 きく, Penck · Brückner の貢献抙第四紀研究史において 不滅であろう、筆者の論旨は, アルプスの沓河時代の区 分単元として確立された氷期・間氷期打よびそれらの亜 期が，第四紀の年代区分単元として，そのまま世界的基 準となり得るかどうかという点にある.アルプスの氷 河時代を無視ないし軽視できるというのでもないし， Penck の偉業をひぼうしようとするものでもない，他の
中川 久 夫

Hisao Nakagawa

項についても同様で, 従来, 編年の基準として用いられ てきたものを, その模式地で見, また現在とてで行なわ れている研究に照らしあわせてみるとどうなっているか ということを記し，第四紀年代区分と模式層準のあり方 を考える材料としたいのが趣旨であることをご理解いた だきたい. 別の機会（中川：1971）に下部更新統の問題 について述べたのも同じ趣旨による.

ヨーロッパの第四紀研究からわれわれは多くを学んで きた・その伝統に敬意を表し, それから受けた恩恵に感 
謝しなくてはならないが，ここでわれわれのヨーロッ パからの学び方の歴史をふり返ってみる必要があるうと 筆者は考えている. これに対し，ご評言はヨーロッパに おける研究史そのものに梁い関心をもつ立場からなされ たように思われる. $2 \cdot 3$ の記述について，あきれたり 驚いたりされたというのは，おそらく，このような立場 のちがいから出たことのようで，一部の方々がこのよう な感想を抱かれるであろうことは，筆者が予期しなかっ たことではない，アルプスの水期編年と海水面運動とが きり離せない関連をむっているのは周知の事実であっ て, 両者の経過の対応は, 野外の事実によって確証され ているにちがいないと思っている方は他にも少なくない であろう、筆者自身, これはアルプスと北欧の水期の対 比や, Rheingletscher と Rheingrabenの 更新統の対比 などとともに，すでに確証された周知の事実であるもの と信じていた．ところが現地で確かめてみるとそうでは なく, 逆に, Woldstedt 一門の後継者と目されている Luttig, Brunnacker, Richter をはじめ, 地元の現役の 研究者から，それらの関係が確立されているというのな らその根拠は何か，と問いただされた. 筆者はこのよう な問題に関する知識を, 大家の総括的著作などから得て いたように思う.われわれが周知の事実と思っているこ とも，現在その問題にとり組えでいる人たちにとって は，必ずしも解決ずみのこととは限らず，また全く別の 考え方さえ進められていることがある. 今まで，ヨーロ ッパやアメリカから学ぶ際に，あまり性急に過ぎはしな かったろうか, のみこみやすい形になったものだけをう のみにしてはいなかったろうか，と筆者は反省してこの 論説を書いた。

上記のような趣旨にかかわらず，ご理解いただけなか った点があるのは，全く筆者の責任で，市原氏のご指摘 に感謝するとともに，ご証言中，やや詳しく記された 2 項について補記させていただく。

Paar 水期 Riss 水期は，他の間水期と同格の間水期 をはさむ 2 氷期に 編成がえされるべきものであるとし $\tau$, Schaefer (1968) がその古期のものに提唱した水期 名で, 新期のものに Riss 氷期の名を残している. 従来 Riss I と呼ばれていたものを独立されたと見てよいよう に思う.やはり Schaefer (1956) の提唱した Biber 水 期とともに，Paar 氷期は一般にはまだ認められていな い. 本交中にもふれたが, ドイツ各地で, 古土壤の研究 から，承期・間水期のくり返えしは $4 \sim 5$ 回にとどまら ないという主張が行なわれている. 亜期と主期の数え方 のちがいという程度の主張ではなく，いわば第 1 級の気
候悪化の回数がふえる傾向にある. Biber や Paar はこ れらとは独立に提唱された氷期で，Donauをも含む Schaefer の 7 水期が，たと党ば， Rhein 中〜下流沿岸 で Brunnacker et al. (1969) が認めた 7 回（またはそれ 以上）の水期とどのように対応するかというようなこと は，双方ともにまだ考光ていないようである。なお， Ingo Schaefer 教授は現在アルプス前縁地域を最も活発 に調査している研究者であるう. 新設の Regensburg 大 学で重要な役割をもったため, ここ $2 \cdot 3$ 年, 研究に専 念できなかったようであるが，そろそろ落ちついた模様 で，今後の成果に注目したい。

Rheingletscher と Rhein 中.下流部の対比両地 区の更新統の対比は, 新期のものについてはほぼ可能の ようである.すなわち, Rheingletscher の Würm 主期 の堆積物は Rhein 中流部の主低位段丘磻層に 対比され ていて，異説はないようである. それより古期になる と，Rhein 中流部で中位段丘を認めるかどうかという問 題からはじまって, いく通りかの対比法があり, 決して Woldstedt の説のみではない. 本文中で沙略してしま ったが，この対比の困難さには別の問題もからんでい る. Rheintal は Rheinisches Schiefergebirge と Schwarzwald 南縁との 2 か所の 狭险部によって, 3 部分に わかれるが，その中部を筆者は中流部として記述した。 この部分は Oberrheinische Tiefland と呼ばれているの でことわりなしにこれを中流部としたのは不注意であ ったかもしれない：このため市原氏をはじめ読者諸賢に ご理解いただけなかった点があったならおわびする。

Rheintal をこのように3 分したとき, Basel 付近は中流 部に含められてよいと考えるが，これに接しているのは Rheingletscher ではなく，ユラ山脈北麓の氷河区であ る. Rheingletscher .と重複している Bodensee 付近一帯 を含む Rhein 上流部と，前記の中流部との間で，Rhein は地質構造上，きわめて注目すべき部分を通過してい る. この部分は南ドィツ三角帯 (Süddeutsches Dreieck) と呼ばれる構造区の南西の頂点に当たり, 北からのびる Schwarzwald の南端をかすめて，Rhein はこれとほほ 直角に西流して, 中流部の Rheintalgraben にはいる. Rheintalgraben の変動は UMP の主題のひとつであっ たと聞くが，これが第四紀を通じて進行していることは 明らかのようである (Mueller et al. : 1969, Sitter : 1969 など). 中・下流間の段丘分布が中断する部分も，やは り構造上，注目すべきところに当たり，その西側には Eifel 火山地域があって, 第四紀の活動が知られている. このように, Rheintal における段丘の対比は新期地殼 
変動を十分考慮にいれて行なわれる必要があるととも に，中〜下流部は，本交中に記した Main 沿岸地域と同 様の, 地形発達史に拈ける気候支配を考慮しなくてはな らない地域である，実際にこれらの事項は検討されてい て，それぞれの要素の比重のおき方で，いく通りむの考 え方がなされているようである。

\section{2. 杉村新氏の評言に関連して}

層位学的編年において，模式地をるうけるという伝統 的な方法は，杉村氏の言われるとおり，やはり最も有効 な方法であると思う．水期区分は気候变化による年代区 分であるが，これにも模式地をるうけ，標準層序を定め るのが妥当であるう. Penck は 1901 年にアルプスの水 河時代を区分した際に，Chamberlin が北米の個々の水 期に地名を付して命名したこと (Geikie：1894)，Geikie （1895）が北欧で同じ方法をとったことを評価して，こ の方法を採用している (Penck-Brückner : 1901-1909, p. 109-111). 氷期名をアルファベット順に並ベるとい う趣旨は，これだけをとりあげると，今日の感覚ではあ まりいただけないが，「将来さらに多くの氷期が認めら れたときのために，間隔を执いてアルフォベット順に並 べる」(ibid，p. 110) としている卓見に，この仕事につ いての自信のほどもらかがわれる。

考古学に扮ける文化期にも模式交化とでもいうものが あり，模式交化にはやはり模式遺跡（標準遺跡）がある と考光てよいであろう，日本のみならず，各国の交化編 年の際に，よく引用されているのがフランスの遺跡交化 である. Abbevillian, Acheulian, Tayacian, Micoquian, Mousterian, Perigordian, Aurignacian, Gravettian, Solutrean, Magdalenian, Azilian, Tardenoisian などが これで，その大部分の模式地はフランス北部と南西部に ある. 上記のうち, Solutrean の模式地だけがアルプス 西緣の Saône 沿岸にあるが，乙れを除くと，大部分の 標準遺跡は Seine 水系と Somme の沿岸および Garonne 水系の沿岸に集中している，遺跡法必ずしも段丘上にあ るとは限らないが，乙れらの水系にそっては段丘群が発 達し, フランス北部の場合, 段丘むその後背地むレスに 蔽われている．英仁海峡や大西洋沿岸のものをも含め て，これらの段丘群はかなりよく調べられているようで ある. フランスでも，上記のような諸交化期をアルプス の水期編年区分に 対比して位置づけをしている，しか し，実際には，レス層序における寒冷期をが゙光て，そ の何番目のものに遺跡があたっているか，といった対応 をさせているので, 結局, その順序を表現するのにアル プスの永期名を借用しているに過ぎない，INQUA 第 8
回国際会議の組織委員長をつとめた J. Dresch 教授は, その下準備のため開催の 2 年ほぞ前に来日されたが，そ の折，本学会の数人の方々とともに同教授と歓談したこ とがある，同席された方はご記憶かと思うが，その際に もこのことを質問したことがある，対比されているとい う返答であったが，ぞのようにして対比をしているかと 重ねて尋ねたら，確実に対比することはできないという 返事であった。これは現地で研究者汇聞いてみた時と全 く同様であった。

レスと段丘とがそろっている地域の遺跡の場合，しか む段丘が海岸地域まで追跡される場合，日本の火山灰と 段丘の地域の遺跡と同様に，レスまたはレスと段丘の層 序のなかで位置づけられるなら，もっとすっきりしたも のになる可能性がある．この場合，たと光ば英伀海峡沿 岸と日本の海岸段丘が対比されるなら，アルプスの水期 との関係は確かめられないとしても，日本の旧石器包含 層と著名なフランスの標準遺跡との関係はつくはずであ る.このように考えてみると，氷期編年はここではむし ろブレーキのような役目をさえしていて，標準層序のあ り方，あるいは評価のしかたなどの点で問題をなげかけ ているように思われる。このようなとと関して，英国 の研究者の態度は興味樑い.West (1968) の著作などに おけるこの問題の扱い方はわれわれに教えるところがあ るように思う。

\section{引用交献}

Brunnacker, K., R. Streit und W. Schirmer (1969) Der Aufbau des Quartär-Profils von Kärlich/Neuwieder Becken (Mittelrhein). Mainz. Naturw. Arch., 8, $102-133$.

Geikie, J. (1894) The great ice age and its relation to the antiqity of man. $3 \mathrm{rd}$ ed., $850 \mathrm{pp}$. Stanford, London.

Geikie, J. (1895) The classification of European glacial deposits. Jour. Geol., 3, 241-270.

Mueller, S., E. Peterschmitt, K. Fuchs and J. Ansorge (1969) Crustal structure beneath the Rhein-graben from seismic refraction and reflection measurements. Tectonophys., 8, 529-542.

Schaefer, I. (1968) The succession of fluvioglacial deposits in northern Alpine foreland. In Glaciaiion of the Alps, Richmond, G. M., ed., VII INQUA Congr. Proc. 14, Univ. Colorado Studies, Ser. Earth Sci., 7, 9-14.

Sitter, C. (1969) The sedimentary trough of the Rheingraben. Tectonophys., 8, 543-560.

West, R. G. (1968) Pleistocene geology and biology. 377 pp. Longmans, London. 